\title{
OPTIMALISASI MEDIA ONLINE SEBAGAI SOLUSI PROMOSI PEMASARAN UMKM DI SEMARANG PADA MASA PANDEMI COVID-19
}

\section{OPTIMALIZATION OF ONLINE MEDIA AS A SOLUTION FOR MSME MARKETING PROMOTION IN SEMARANG THROUGH COVID-19 PANDEMIC}

\author{
Rotumiar Pasaribu \\ Universitas Katolik Soegijapranata \\ Email: rotumiar@unika.ac.id
}

\begin{abstract}
The period of Covid-19 pandemic is a difficult time for several aspects including world of marketing. This also hapens by MSMEs business actors. Through mentoring for several partners in the Marketing Communication Subject, it is important to find out whether the use of online media can help the defense and life journey of MSMEs. The benchmarks used to find out the accuracy of online media use can be seen in terms of transmission mode, time, context, format and receiption. Respondents who are research partners are MSMEs actors who are still new and do not have a stable marketing mode. In addition, the selection of respondents was also seen from the decline in sales during the Covid-19 pandemic. The results showed that online media had a positive impact on the stability of business life. The combination of the correct mode of transmission, timing, context and format in the online media has a positive impact on both communication and sales growth. In addition, marketing communication tools such as advertising, direct marketing, sales promotion, E-WOM and public relations can be kept organized using online media. The marketing tools that show the most significant results are the use of direct marketing and sales promotion. Even so, business actors admit that promotional messages still have a greater impact if done by face-to-face.
\end{abstract}

Keywords: MSMEs, online media, marketing promotion, Covid-19 pandemic

\begin{abstract}
Abstrak
Masa pandemi Covid-19 menjadi masa yang sulit bagi beberapa aspek termasuk dunia pemasaran. Hal tersebut juga dirasakan oleh para pelaku usaha UMKM. Melalui pendampingan bagi beberapa mitra pada Mata Kuliah Komunikasi Pemasaran maka penting untuk mencari tahu apakah penggunaan media online dapat membantu pertahanan dan perjalanan hidup UMKM. Tolok ukur yang digunakan untuk mencari tahu ketepatan penggunaan media online dapat dilihat dari segi mode transmisi, waktu, konteks, format dan reception. Responden yang menjadi mitra penelitian adalah para pelaku UMKM yang baru menjalankan usahanya dan belum memiliki mode pemasaran yang stabil. Selain itu, pemilihan responden juga dilihat dari merosotnya penjualan selama masa pandemi Covid-19 ini muncul. Hasil penelitian menunjukkan bahwa media online memberikan dapak positif bagi stabilitas kehidupan usaha. Kombinasi dari mode transmisi, waktu, konteks dan format yang tepat pada media online ini menghasilkan dampak positif pada timbal balik, baik dari segi proses komunikasi maupun dari peningkatan penjualan. Selain itu alat komunikasi pemasaran seperti periklanan, direct marketing, sales promotion, E-WOM dan public relations dapat tetap diorganisir dengan menggunakan media online. Alat pemasaran yang paling menunjukkan hasil yang signifikan adalah penggunaan direct marketing dan sales promotion. Meskipun demikian, para pelaku usaha mengaku bahwa pesan promosi pemasaran masih terdampak lebih besar jika dilakukan dengan tatap muka langsung.
\end{abstract}

Kata kunci: UMKM, media online, promosi pemasaran, pandemi Covid-19 


\section{PENDAHULUAN}

Ajakan Kementerian Komunikasi dan Informatika untuk memanfaatkan teknologi digital dalam memasarkan usaha mikro, kecil menengah (UMKM) agar menembus pasar global bukan suatu yang sulit untuk diterapkan. Hal tersebut dikuatkan oleh pernyataan Direktur Informasi dan Komunikasi Perekonomian \& Maritim Kemkominfo, Septriana Tangkary, yang mengatakan bahwa lebih dari 18 persen UMKM telah memasuki pasar ekonomi digital. Di mana 37 persen dari 60 persen diantaranya adalah pengguna media sosial seperti WhatsApp group, Facebook dan lainnya yang digunakan sebagai media penyalur pemasaran (Zuraya, 2020).

Informasi tersebut disampaikan tepat sebelum pandemi Covid-19 ini berlangsung. Akan tetapi dampak pandemi yang mengubah tatanan hampir segala bidang ini juga berimbas terhadap pelaku usaha termasuk UMKM. Hidup segan mati tak mau, setidaknya itulah peribahasa yang dapat menggambarkan kondisi pelaku UMKM di tengah pandemi Covid-19 saat ini. Penularan virus Corona yang demikian cepat dan masif telah memaksa pemerintah menerapkan Pembatasan Sosial Berskala Besar (PSBB). Kebijakan tersebut berdampak terhadap berbagai aktivitas bisnis pelaku UMKM dan terhadap perekonomian. Namun, pemerintah harus memutuskan pilihan antara kepentingan ekonomi atau keselamatan warga negara. Sudah pasti dengan penuh perhitungan dan konsekuensi risikonya, keselamatan warga negara adalah di atas segala-galanya (Simanjorang, 2020).

Berkaca pada krisis moneter 1998 dan krisis keuangan global 2008, tatkala perusahaanperusahaan skala besar banyak yang tumbang, sektor UMKM justru tampil sebagai penyelamat dan penopang perekonomian nasional. Ketangguhan UMKM menjadi modal utama, membawa perekonomian nasional selamat dari krisis dan perlahan tapi pasti perekonomian kita dapat pulih kembali. UMKM saat itu mampu menggerakkan ekonomi akar rumput dan menjaga daya beli masyarakat. Namun, kini kondisinya jauh berbeda kala pandemi Covid-19 melanda negara kita. UMKM tak lagi tangguh, lumpuh, tidak dapat lagi diandalkan sebagai penopang perekonomian bangsa. Pangsa pasar yang dimilikinya, berupa kebutuhan masyarakat seharihari, baik sandang maupun pangan, menyempit. Dalam ruang gerak yang sudah teramat sempit, aneka produk yang disiapkannya tidak menjadi transaksi yang mampu menggerakkan ekonomi dan perputaran uang.

Usaha mikro, kecil dan menengah (UMKM) justru menjadi sektor paling rentan kena hantaman pandemi virus corona. Sektor ini disebut ekonom tak bisa lagi menjadi penyangga perekonomian seperti saat krisis ekonomi dan keuangan 1998 dan 2008. Agar UMKM tetap bisa berproduksi dan terhindar dari kejatuhannya, Presiden Joko Widodo meminta realokasi APBN dan APBD ke tiga bidang yang salah satunya UMKM. Saat Indonesia mengalami krisis moneter 1998, UMKM menjadi penyangga ekonomi nasional sebagai penyerap tenaga kerja dan penggerak perekonomian. Sementara pada 2008 di masa krisis keuangan global, UMKM tetap kuat menopang perekonomian. Namun, Ekonom Senior Institute for Development of Economic and Finance (INDEF), Enny Sri Hartanti menyatakan bahwa sektor ini tetap tak bisa menahan krisis yang disebabkan Covid-19 (Irham, 2020).

Kementerian Koordinator Bidang Perekonomian mencatat sebanyak 301.115 usaha mikro kecil dan menengah (UMKM) beralih ke usaha digital selama pandemi COVID-19. Menko Airlangga mendorong pelaku UMKM lainnya untuk memanfaatkan momentum ini untuk 
memperluas penetrasi pasar karena terjadi perubahan pola konsumsi pasar dari konvensional menuju digital.

Kementerian Koperasi dan Usaha Kecil Menengah (UKM) mencatat ada 64,1 juta pelaku UMKM di Indonesia pada semester pertama 2019. Dari jumlah itu, sebanyak 63,3 juta atau 98,6 persen merupakan pelaku usaha mikro, sisanya pelaku usaha menengah (1,2 persen) dan menengah (0,09 persen). Dari 64,2 juta pelaku UMKM itu, baru 13 persen atau sekitar 8,3 juta UMKM di antaranya yang sudah memanfaatkan digitalisasi dalam menjalankan usahanya (Wiguna, 2020).

Dalam lingkup komunikasi pemasaran, pemilihan media merupakan jembatan penyeberangan pesan promosi yang akan disampaikan kepada konsumen. Pemilihan media dilandaskan oleh jenis produk yang akan dipasarkan, target sasaran, waktu pengiriman pesan dan biaya promosi. Setiap media yang menjadi pilihan adalah pertimbangan untuk keefektifan penerimaan pesan oleh konsumen.

Media digital berbasis online menjadi sasaran pelaku usaha, khususnya UMKM karena media ini dapat menjangkau sasaran secara luas bahkan secara personal. Belum lagi beberapa platform seperti media sosial menjadi media pertama dan unggulan bagi UMKM karena biaya yang terbilang murah dan mudah untuk mengaplikasikannya. Hanya saja apakah media digital ini menjadi pilihan tepat mengingat jutaan penduduk hadir dalam dunia tersebut dan menjadikan dunia digital riuh, macet dan padat. Imbasnya, bagi konsumen yang hendak mencari informasi meskipun dimudahkan akan tetapi juga dibingungkan dengan ragamnya informasi yang diterima.

Oleh sebab itu, bagi pelaku usaha, khususnya UMKM perlu mempertimbangkan pemilihan media yang tepat dalam mempromosikan produknya agar pesan dan strategi yang direncanakan berjalan dengan baik dan lancar. Agar tepat dalam penggunaan media, pelaku UMKM perlu mempertimbangkan mode transmisi, waktu, konteks, format dan penerimaan sebagai tolok ukur.

\section{$U M K M$}

Menurut Undang-undang Nomor 20 Tahun 2008 tentang Usaha Mikro, Kecil dan Menengah (UMKM), usaha kecil didefinisikan sebagai kegiatan ekonomi produktif yang berdiri sendiri. Usaha ini dilakukan perorangan atau badan usaha yang bukan merupakan anak perusahaan atau bukan cabang perusahaan yang dimiliki, dikuasai atau menjadi bagian baik langsung maupun tidak langsung dari usaha menengah atau usaha besar serta memenuhi kriteria lain.

Dalam UU tersebut juga dijelaskan perbedaan kriteria UMKM dengan Usaha Besar. 1) Usaha Mikro: aset maksimal 50 juta rupiah (tidak termasuk tanah dan bangunan tempat usaha) dan omzet maksimal 300 juta rupiah per tahun. 2) Usaha Kecil: aset lebih dari 50 juta hingga 500 juta rupiah (tidak termasuk tanah dan bangunan tempat usaha) dan omzet maksimal lebih dari 300 juta hingga 2,5 miliar rupiah per tahun. 3) Usaha Menengah: aset lebih dari 500 juta hingga 10 miliar rupiah (tidak termasuk tanah dan bangunan tempat usaha) dan omzet lebih dari 2,5 miliar hingga 50 miliar rupiah per tahun. 4) Usaha Besar: aset lebih dari 10 miliar rupiah (tidak termasuk tanah dan baangunan tempat usaha) dan omzet lebih dari 50 miliar rupiah per tahun (Putri, 2019). 
Kristiyanti \& Rahmasari (2015) menyatakan bahwa sektor industri yang hampir tidak terdampak sedikit pun oleh krisis global adalah UMKM. Pernyataan tersebut juga didukung oleh Dahlan (2017) yang menyatakan bahwa UMKM bebas hambatan dan tahan terhadap perubahan dan dinamika perubahan lingkungan dan global. Akan tetapi peristiwa pandemi Covid-19 yang hampir mengakibatkan krisis ekonomi secara global justru sangat memberikan dampak signifikan terhadap industri UMKM.

Data Kementerian Koperasi dan UKM Republik Indonesia, Sensus Ekonomi dari Badan Pusat Statistik pada 2016 menunjukkan besarnya kontribusi UMKM. Sumbangan UMKM terhadap perekonomian Indonesia antara lain UMKM menyerap hingga 89,2 persen dari total tenaga kerja, menyediakan hingga 99 persen dari total lapangan kerja, menyumbang 60,34 persen dari total PDB nasional, menyumbang 14,17 persen dari total ekspor, serta menyumbang 58,18 persen dari total investasi (Putri, 2019). Oleh sebab itu, UMKM yang telah memberikan kontribusi terhadap perekonomian Indonesia perlu perhatian lebih agar masa hidup setiap UMKM dapat terus berlanjut.

Kondisi pandemi yang mengakibatkan adanya physical dan social distancing memengaruhi bentuk proses pemasaran yang terjadi. Jika sebelumnya para konsumen sangat antusias melakukan belanja secara langsung, situasi pandemi mengakibatkan konsumen lebih mengandalkan media pemasaran yang memfasilitasi proses belanja tanpa kontak fisik. Perubahan tersebut mengakibatkan banyak pelaku usaha khususnya UMKM juga melakukan adaptasi karena adanya beberapa perubahan budaya berbelanja mulai dari komunikasi, distribusi dan pembelian produk pemasaran. Maka dari itu pelaku usaha UMKM harus memerhatikan dengan baik bagaimana mereka melakukan komunikasi pemasaran terutama dalam penggunaan media pemasaran yang tepat agar konsumen tetap pada standar aware, interest, desire, dan action.

\section{Komunikasi pemasaran}

Unsur dalam komunikasi seperti sumber, pesan, media dan penerima pesan merupakan unsur penting pula dalam lingkup pemasaran. Setiap bagian secara strategis disusun secara integral agar tujuan akhir dari pemasaran yaitu aksi pembelian menjadi dampak dari proses komunikasi pemasaran. Semua organisasi baik besar maupun kecil, bersifat komersial, pemerintahan, pengabdian, pendidikan dan organisasi nonprofit lainnya membutuhkan komunikasi kepada seluruh pemangku kepentingan. Baik pelayanan dalam bentuk barang maupun jasa agar dapat menjalankan usahanya maka butuh untuk bekerja sama dan berkoordinasi dengan para pemangku kepentingan (Chianasta \& Wijaya, 2014).

Semua organisasi, besar dan kecil, komersial, pemerintah, amal, pendidikan, dan organisasi nirlaba lainnya perlu berkomunikasi dengan berbagai pemangku kepentingan. Hal ini mungkin untuk mendapatkan bahan dan layanan untuk menjalankan aktivitas bisnis mereka atau untuk berkolaborasi dan berkoordinasi dengan orang lain untuk mengamankan distribusi barang dan layanan yang sesuai dengan yang dikehendaki. Selain itu, ada ragam orang-orang calon konsumen yang bebas memilih di antara ratusan dan ribuan produk yang ditawarkan. Komunikasi pemasaran memberikan aktivitas inti agar semua pihak yang berkepentingan dapat memahami tujuan produk dan menghargai nilai barang dan jasa yang ditawarkan.

Secara tradisional, ada lima alat komunikasi pemasaran utama yaitu periklanan, promosi penjualan, penjualan pribadi, hubungan masyarakat, dan pemasaran langsung. Selain itu, ada 
media di mana ruang dan waktu dapat dibeli atau digunakan untuk menyampaikan pesan kepada khalayak sasaran.

Pada tahun 1990-an, pemasaran langsung menjadi alat yang lebih menonjol karena teknologi telah memungkinkan bentuk komunikasi dengan menarik secara pribadi dan langsung ke pelanggan sasaran. Perubahan ini memperkenalkan format media baru dan perkembangan selanjutnya dari internet dan teknologi digital terkait telah mempercepat perubahan dalam industri komunikasi pemasaran. Sekarang ada banyak sekali peluang untuk menjangkau khalayak, dengan internet mewakili saluran komunikasi baru namun menantang.

Pada saat yang sama ketika dunia media telah terpecah menjadi banyak bagian yang berbeda, demikian pula khalayak yang perlu berkomunikasi dengan organisasi. Konsumen kini memiliki berbagai cara berbeda untuk menghabiskan waktu luang mereka. Beberapa konsumen memilih untuk memasukkan media sebagai bagian dari relaksasi mereka, sekarang tidak hanya memiliki televisi komersial, majalah umum dan khusus atau bioskop akan tetapi, internet dengan ledakan situs web menawarkan sumber informasi yang tampaknya tak ada habisnya, peluang untuk membeli secara daring, dan bentuk hiburan global dan 'web 2.0' yang menawarkan berbagai peluang media sosial. Dunia komunikasi pemasaran cerah, mengasyikkan, terkadang tidak dapat diprediksi, namun selalu menantang dan berkembang (Fill, 2009).

\section{Media online bagi pemasaran}

Internet menyediakan berbagai macam aktivitas, termasuk surat elektronik, akses informasi global dan sistem temu-balik, grup diskusi, permainan multipemain dan fasilitas transfer file, yang kesemuanya tidak hanya membantu mengubah cara kita berpikir tentang komunikasi pemasaran, tetapi juga berdampak pada strategi bisnis, struktur saluran pemasaran, hubungan antarorganisasi dan konfigurasi bauran komunikasi pemasaran.

Internet berdampak pada pemasaran dalam dua cara utama yaitu distribusi dan komunikasi. Yang pertama menyangkut saluran distribusi dan pemasaran. Internet menyediakan rute baru yang lebih langsung ke pelanggan, yang dapat menggantikan atau melengkapi pengaturan distribusi/ saluran saat ini. Elemen kedua menyangkut internet sebagai media komunikasi. Ini menyediakan cara untuk menjangkau khalayak baru yang sangat besar dan memungkinkan penyediaan informasi dalam jumlah besar. Kedua elemen tersebut bergabung sebagai e-business dan e-commerce untuk memberikan keuntungan bagi pembeli dan penjual (Fill, 2009).

Tidak seperti media tradisional arus utama seperti televisi dan radio, banyak konsumen telah beralih ke perubahan evolusioner dalam gaya hidup dan ke arah penggunaan media sosial. Dengan banyaknya "ruang" di dunia maya, media online telah menciptakan pusat informasi yang kokoh bagi pemasar dan konsumen. Tujuan pembuatan perangkat jaringan ini adalah untuk menyediakan saluran komunikasi yang efisien dan tepat waktu. Tantangan yang dihadapi perusahaan saat ini adalah integrasi penawaran dengan gaya hidup konsumen tersebut. Internet telah mencapai tahap di mana ia menjadi outlet media "go to", di atas semua saluran komunikasi media tradisional lainnya. Meski konsumen masih memanfaatkan media tradisional, tren penggunaan media telah berubah drastis. Sekarang, konsumen memiliki kontrol lebih besar atas apa yang ingin mereka gunakan, dengar, dan lihat, dan khalayak diberi kesempatan untuk membuat konten media secara bebas oleh mereka sendiri. Lebih jauh, 
penelitian menunjukkan bahwa kehadiran internet telah mengubah cara orang mengkomunikasikan informasi (Moriuchi, 2016).

\section{Efek penggunaan media bagi pemasaran}

Penyampaian pesan pemasaran akan efektif jika pemilihan media telah dipertimbangkan dengan baik. Setiap media memiliki kelemahan dan kelebihan. Oleh sebab itu, salah satu tujuan utama dalam pemilihan media pemasaran yang efektif adalah penyesuaian antara unsur dari marketing mix dengan khalayak sasaran. Dengan demikian, pesan yang disusun akan lebih efektif.

Hal tersebut didasari oleh ragamnya media akan menimbulkan efek atau dampak yang berbeda dari respons khalayak. Salah satu pendekatan untuk mengidentifikasi perbedaan antara media dan respons kita terhadap mereka adalah dengan menggunakan klasifikasi mode transmisi, waktu, konteks, format dan penerimaan. Masing-masing variabel mewakili perbedaan dalam kesempatan dan penggunaan (Pickton \& Broderick, 2005).

'Mode transmisi' mewakili aspek 'teknis' dari media dan secara signifikan memengaruhi cara media disediakan bagi khalayak. Mode transmisi memiliki dampak besar pada bagaimana kita 'berpartisipasi' dalam media. "Media adalah pesannya!" (McLuhan, 1964) telah menggambarkan media sebagai ekstensi manusia, tidak kalah penting dari tangan, mata atau telinga, dan memiliki kedalaman implikasi pada tindakannya, tanggapan dan organisasi budaya. Namun tidak semua media sama. Yang menjadi poin penting adalah bahwa hubungan kita dengan media bervariasi dari satu media ke media yang lain dan karena itu, pesan komunikasi pemasaran terpengaruh.

'Waktu' mengacu pada di mana media (dan komunikasi pemasaran) dapat dilihat atau didengar. Ini terkait erat dengan 'konteks'. Semakin banyak media tersedia untuk kita 24 jam sehari, meskipun mereka dapat digunakan oleh kelompok target khalayak yang berbeda. Dalam konteks ini media memberikan kesempatan bagi kahalayak untuk menentukan waktu yang tepat untuk menerima pesan tersebut melalui sebuah media yang telah dipilih. Bahkan jika tidak sesuai maka khalayak akan mengabaikan atau bahkan marah.

'Konteks' dapat terkait dengan 'konteks media' yang terutama merupakan iklim editorial dan periklanan tempat komunikasi pemasaran berlangsung. Kendaraan media mengembangkan 'atmosfer' mereka sendiri yang disampaikan oleh nada editorial yang mereka adopsi. Beberapa kendaraan media diakui karena prestise mereka (The Tatler), beberapa karena keahlian mereka (Scientific American), beberapa untuk humor dan ketidaksopanan mereka (Punch), beberapa karena ketidakberpihakan mereka. Beberapa media mengandung sangat sedikit iklan, beberapa mengandung banyak atau mungkin sepenuhnya dikhususkan untuk iklan. Sebuah iklan terlihat pada halaman dengan banyak orang lain dapat membuat efek yang berbeda dengan langsung mengirim surat melalui pos. Konteks juga dapat merujuk pada lingkungan fisik dan sosial di mana media tersedia. Pada titik ini kelas media sangat bervariasi.

'Format' berkaitan dengan fleksibilitas komunikasi pemasaran yang difasilitasi oleh masing-masing media seperti tata letak, ukuran, penggunaan warna, grafik, desain, tipografi, dan gaya umum komunikasi pemasaran. Masing-masing media menciptakan lebih banyak atau lebih sedikit fleksibilitas dalam format yang diizinkan. Poster 'situs super' dapat menampilkan gambar setinggi beberapa kaki. Bila 'mode transmisi' menentukan apa yang mungkin, 'format' pada akhirnya adalah seberapa baik ini digunakan dalam penciptaan komunikasi pemasaran. 
Telah diulas bahwa 'mode transmisi' terkait dengan media itu sendiri sebagai entitas fisik. Sementara 'penerimaan' terkait dengan khalayak yang menerima pesan melalui media. Pada akhirnya, itu adalah respons mereka terhadap media dan pesan-pesan yang dikandungnya. Respons mereka dipengaruhi oleh media dan kecenderungan penerima pada saat penerimaan. Alasan mengapa waktu, konteks dan format menjadi penting adalah karena efek kumulatif yang menginduksi hubungan antara media komunikasi pemasaran dan pesan, serta khalayak mereka.

\section{METODOLOGI PENELITIAN}

Tulisan ini berangkat dari mata kuliah yang diampu oleh penulis yaitu Komunikasi Pemasaran. Mata kuliah tersebut berkegiatan untuk melakukan pendampingan terhadap mitra UMKM oleh mahasiswa. Terkhusus karena situasi social dan physical distancing akibat pandemi Covid-19 maka kegiatan service learning ini dilakukan secara online. Selain itu, kegiatan service learning ini adalah pendampingan UMKM dengan mengaplikasikan Komunikasi Pemasaran Terpadu. Dalam hal ini, penulis melakukan pengamatan penggunaan media online sebagai sarana pemasaran khususnya pada masa pandemi.

Metode penelitian dengan pendekatan kulitatif ini menggunakan teknik observasi dan wawancara untuk mengumpulkan data. Mitra UMKM pada kelas Komunikasi Pemasaran menjadi responden dalam penelitian ini. Total responden adalah sepuluh pelaku usaha UMKM dengan beberapa kriteria yaitu: UMKM baru berdiri tidak lebih dari tiga tahun; memiliki kurang dari sepuluh karyawan; dan jika menggunakan media sosial adalah dengan jumlah pengikut (follower) kurang dari 3000. Hal tersebut menjadi sasaran service learning dan penelitian karena mitra/ respoden tersebut masih baru dan metode pemasaran mereka belum terorganisir dengan baik. Selain itu responden penelitian tersebut dianggap paling terdampak oleh pandemi karena belum matangnya metode pemasaran dan produk yang belum dikenal baik oleh khalayak sasaran terkait beragammya pesaing.

\section{HASIL DAN PEMBAHASAN}

Krisis segala aspek yang didasari oleh kasus pandemi Covid-19 telah mengubah segala bentuk kebudayaan atau kebiasaan. Bahkan setelah Covid-19 ini berakhir penyebutan 'New Normal' atau kenormalan baru bukan sebuah bentuk budaya yang telah kembali seperti sedia kala, akan tetapi bagaimana adanya kebiasaan baru yang terjadi setelah Covid-19 berangsur pulih. Meski beberapa budaya lama tetap ada yang berjalan. Salah satu budaya yang berlangsung baru adalah optimalisasi media digital berbasis daring sebagai sebuah komunikator, pesan, media dan komunikan. Walaupun tatanan lama sudah beradaptasi dengan media ini, akan tetapi perubahan besar telah terjadi. Banyak kegiatan akan dimudahkan dengan penggunaan media digital yang telah disahkan atau diterima dalam berbagai urusan. Hasilnya, media berbasis online ini justru menjadi penyelamat, pembantu dan pilihan tepat untuk berbagai kegiatan termasuk pemasaran.

Seperti yang telah disampaikan pada latar belakang bahwa pemerintah berharap para pelaku usaha UMKM menggunakan media online sebagai media pemasaran bahkan sebelum Covid-19 ini muncul. Oleh sebab itu, penelitian yang berdasar pada service learning pada pelaku usaha UMKM ini menjadi menu yang tepat sehingga penelitian ini membuahkan hasil. 
Hasil wawancara menunjukkan bahwa para pelaku usaha UMKM menganggap media online sangat tepat digunakan dan bermanfaat di masa pandemi ini. Selain karena harus meminimalisir aktivitas luar ruang, media online dianggap media paling cepat untuk melakukan sharing informasi kepada para konsumen. Selain karena konsumen sangat erat hubungannya dengan media online, media ini juga sangat cepat dan murah dalam menyebarkan pesan promosi kepada konsumen.

Penyampaian pesan promosi pemasaran yang berdasar pada alat komunikasi pemasaran seperti periklanan, direct marketing, sales promotion, E-WOM dan public relations dapat sekaligus diaplikasikan melalui media online. Para pelaku usaha dapat mengemas alat pemasaran tersebut dengan seefektif mungkin kepada konsumen melalui media online. Selain itu, para pelaku usaha dapat mengukur efek penggunaan alat tersebut dengan cepat melalui media online. Dengan begitu, pelaku usaha dapat melihat alat mana yang paling efektif yang dapat dilakukan dan diterima oleh konsumen.

Selama pendampingan praktik komunikasi pemasaran yang dilakukan kepada para mitra, tampak bahwa paling banyak respons adalah peggunaan direct marketing karena penyampaian pesan yang dilakukan secara langsung memberikan respons secara langsung pula. Akan tetapi penjualan yang paling membuahkan hasil pembelian paling banyak adalah sales promotion, mengingat banyaknya bonus dan diskon yang ditawarkan pada alat pemasaran ini. Para pelaku usaha dapat menilai dan meriset secara langsung penggunaan media online ini sehingga pelaku usaha dapat menyimpulkan alat mana yang kurang efektif dan bagaimana membuatnya menjadi lebih efektif. Atau, pelaku usaha dapat langsung memilih akan menggunakan alat komunikasi pemasaran yang paling efektif untuk menghemat tenaga dan pikiran. Hal ini menunjukkan, selain optimal, penggunaan media online ini berdampak positif bagi pengembangan pemasaran UMKM.

Dengan adanya media online, pesan pemasaran, seperti media promosi melalui Instagram, WhatsApp, Facebook, Line, dll lebih menarik dan cepat sampai ke pelanggan, sehingga mereka terarik melihat desain promosi, ataupun bonus yang kadang diberikan untuk menambah omzet pemasukan. Apalagi selama pandemi Covid-19, konsumen lebih tertarik mengakses pesanan melalui media online, daripada harus membeli langsung ke tempat pembuatnya. Maka bagi pelaku usaha UMKM, pengalaman di saat pandemi ini dengan menggunakan media online memberikan dampak yang sangat efektif. Media online menjadi platform yang paling tepat untuk penyaluran pesan pemasaran misalnya dengan strategi iklan di Instagram yang dapat membawa kemajuan untuk kunjungan profil walaupun belum tentu diorder. Yang pasti pula pesannya lebih cepat sampai ke target pemasaran. Kelebihan lain adalah adanya penambahan reseller sangat dimungkinkan ketika memanfaatkan media online.

Media online yang paling banyak digunakan khususnya saat pandemi adalah media sosial. Media sosial yang paling banyak diminati baik pelaku usaha maupun konsumen adalah Instagram. Selain berdasarkan survei penggunaan Instagram yang cukup banyak, media sosial ini sangat mudah diakses, diaplikasikan dan dikomunikasikan dengan strategis. Hal tersebut karena Instagram dapat melakukan survei pegunjung sehingga para pelaku usaha akan mudah menembak sasaran pesan pemasaran.

Penggunaan media online khususnya media sosial telah memiliki kelekatan tersendiri bagi para konsumen. Media sosial telah menjadi kartu identitas. Segala informasi baik yang dibentuk atau yang dicari diaplikasikan melalui media sosial. Penggunaan setiap jenis media 
online yang dimiliki konsumen memiliki fungsi tersendiri bahkan dalam melakukan belanja daring. Misalnya media sosial Instagram digunakan untuk mencari informasi secara umum, sedangkan pemesanan akan dilakukan melalui WhatsApp. Oleh sebab itu, hubungan konsumen dengan setiap media berbeda sesuai dengan konsep transmisi pada media. Dengan informasi demikian, pelaku usaha lebih memahami karakter konsumen sehingga pada pesan promosi yang disalurkan melalui media Instagram akan memberi kontak WhatsApp untuk kelanjutan informasi yang lebih detail.

Pemilihan waktu yang tepat akan berguna dan bermanfaat. Selain efektif dalam menyampaikan pesan, dampaknya akan lebih terasa saat melakukan promosi diwaktu yang tepat di media online. Makna tepat juga harus dilandasi waktu konsumen bukan hanya pelaku usaha. Pelaku usaha harus jeli ketika menggunakan media online, kapan saja konsumen itu aktif dalam merespons. Pemahaman yang baik mengenai perilaku konsumen akan membantu pelaku usaha mengatur waktu yang tepat ketika melakukan pesan pemasaran di media online. Hal tersebut dikarenakan konsumen akan bosan atau jenuh ketika terus-terusan diterpa iklan. Bukannya konsumen tertarik justru konsumen akan meninggalkan halaman promosi.

Pemilihan waktu yang tepat juga ditentukan oleh segmentasi pasar sasaran. Misalnya waktu yang tepat dengan melihat pola hidup pangsa pasar atau konsumen Bakoel Djamu diminati oleh pekerja kantoran yang mana mereka biasanya membuka media sosial pada jam sebelum kerja yaitu pukul 08:00 pagi dan waktu istirahat yaitu pukul 12:00 siang dan waktu pulang kerja pukul 17:00 atau pada saat santai malam diatas jam 19:00-21:00. Kasus lain menceritakan bahwa jika follower Instagram terlihat aktif pada siang pukul 12.00 hingga 18.00 sore maka waktu tersebut adalah waktu efektif untuk upload. Keuntungan media sosial Instagram adalah aktivitas konsumen dapat dilihat melalui 'Insight Instagram'. Pemilihan waktu yang tepat juga didasari oleh setiap media yang digunakan. Misalnya jika menggunakan WhatsApp akan lebih efektif jika dilakukan pagi hari dan malam hari. Akan tetapi jika menggunakan media sosial Instagram maka yang tepat adalah pagi sekitar jam 10.00 hingga jam 15.00 .

Pandemi telah mengubah seluruh aktivitas pelaku usaha dan konsumen. Oleh sebab itu pelaku usaha melakukan survei ulang mengenai aktivitas browsing dan belanja para konsumen. Selama melakukan observasi, waktu browsing dan belanja tidak terlalu banyak berubah. Khususnya bagi pelaku usaha makanan. Jam makan baik berat dan ringan masih sama. Kendala banyak muncul karena banyak pelaku usaha juga sama-sama memanfaatkan media sosial selama masa pandemi. Akan tetapi masa ini juga memberikan peningkatan positif karena banyak konsumen yang memanfaatkan belanja online mengingat kebijakan social dan physical distancing.

Pelaku usaha harus tahu follower yang menjadi sasaran pemasaran siapa saja dan mengenal demografi mereka mulai dari usia, jenis kelamin, dan asal daerah mereka. Selain itu, kapan waktu yang mereka gunakan saat menikmati pesan dari media sosial. Dengan keterangan tersebut, maka penyampaian pemasaran dapat dikirim secara tepat waktu. Selain itu, desain dan bentuk pesan promosi dapat diatur sesuai dengan target pasar secara efektif.

Para konsumen menikmati media online seperti sedang berada di supermarket atau mall. Mereka menikmati segala pemandangan yang ada, bahkan media online menawarkan kemudahan yang berkali lipat. Selain tidak lelah karena tidak harus berjalan, para pengguna media online dapat menikmati fasilitas pilih sendiri. Namun, sama halnya ketika konsumen 
berbelanja langsung di supermarket dan mall yang tidak suka ketika banyak pramuniaga dan SPG (Sales Promotion Girl)/ SPB (Sales Promotion Boy) mengikuti konsumen terus menerus dan sibuk memberikan penawaran, media online yang terus memunculkan iklan yang berlebihan juga terasa jenuh untuk dikunjungi. Oleh sebab itu, pelaku usaha harus pandai memahami kebutuhan konsumen.

Pelaku usaha juga harus memahami karakteristik para konsumen seperti media mana yang akan digunakan untuk iklan yang seperti apa, media mana yang digunakan untuk berinteraksi kepada siapa, media mana yang menggunakan pesan yang seperti apa serta media mana yang akan digunakan untuk hal khusus dalam komunikasi pemasaran.

Seperti informasi sebelumnya bahwa Instagram lebih sering digunakan untuk melakukan pesan promosi seperti penggunaan seluruh alat komunikasi pemasaran. Kemudian, WhatsApp lebih digunakan untuk direct marketing dan proses pemesanan. Aplikasi Grabfood dan Gofood lebih digunakan untuk memberikan keterangan harga produk dan proses pemesanan juga. Jelasnya bahwa setiap media sudah memiliki konteksnya masing-masing. Hal tersebut pun telah terbudaya baik dari pelaku usaha maupun bagi para konsumen sendiri. Pemilik media telah membentuk branding tiap-tiap kegunaan dan identitas dari setiap media sehingga membantu para pelaku usaha dan konsumen untuk memanfaatkan setiap media.

Kemudian, pesan pemasaran sangat perlu diperhatikan agar penjualan tepat sasaran. Sama halnya dengan pemilihan waktu yang tepat, penggunaan bahasa juga harus dan perlu mempertimbangkan keberagaman khalayak sasaran. Pelaku pemasaran UMKM pun melakukan berbagai cara agar format dari pesan pemasaran efektif dan efisien.

Proses pembuatan pesan pun harus diperhatikan dengan baik. Hal ini bertujuan untuk menarik perhatian konsumen hingga konsumen mengambil keputusan untuk membeli hingga loyal pada produk UMKM. Beberapa teknik yang dilakukan adalah dengan mendeskripsikan dengan baik dan tepat produk yang ditawarkan, memberikan pesan positif kepada konsumen, menyusun 'Feed Instagram' semenarik mungkin, membuat kampanye peduli lingkungan, membuat giveaway, membuat tagar (\#) dan yang lainnya. Selain menarik, pesan juga harus aktual yang artinya sesuai dengan fakta dan tidak mengada-ada dan pesan akan mudah diterima jika dibentuk senatural mungkin. Kemudian pesan juga harus dibentuk dengan unik namun tidak menimbulkan makda ganda atau ringkasnya adalah mudah dimengerti.

Penyusunan pesan melalui media online ini dapat didukung dalam bentuk poster, video hingga menggunakan testimoni dari endoser. Tiap media yang digunakan akan menentukan gaya pesan penyampaian yang berbeda. Selain karena segmentasi, penggunaan media tertentu juga akan memengaruhi pesan tertentu. Misalnya, pesan di WhatsApp dalam bentuk 'broadcast' kepada banyak orang akan lebih panjang daripada pesan personal.

Setiap produk selain menyesuaikan dengan identitas dari brand yang dibentuk, pesan pemasaran pada setiap media juga disusun secara strategis. Jenis produk juga menentukan tata letak, ukuran, penggunaan warna, grafik, desain, tipografi, dan gaya umum komunikasi pemasaran pada media pemasaran yang digunakan. Misalnya pada produk makanan, ketika pesan direct marketing menggunakan aplikasi WhatsApp maka gaya akan lebih monoton dan sedikit terasa kaku. Sedangkan ketika menggunakan website, Grabfood dan Gofood atau media sosial Instagram akan lebih leluasa dalam memanfaatkan tata letak, ukuran, penggunaan warna, grafik, desain, tipografi, dan gaya umum komunikasi pemasaran. 
Dengan penggunaan pesan yang efektif dan efisien para pelaku usaha menyampaikan bahwa timbal balik dari konsumen akan diperoleh dari bagaimana cara pelaku usaha berkomunikasi. Timbal balik dari konsumen dapat terlihat dari berbagai bentuk yaitu viewer dan comment terhadap pesan pemasaran yang meningkat, peningkatan pembelian dari konsumen, repeat order dari customer, jangkauan pasar yang lebih luas. Bonus tambahan ketika penggunaan pesan pemasaran dengan efektif dan efisien adalah adanya reseller yang ingin bergabung. Hal tersebut menunjukkan bahwa mitra kerja tertarik dengan produk yang dipasarkan.

Karakteristik tolok ukur penggunaan media online pada praktik komunikasi pemasaran terlihat memberikan dampak yang signifikan baik dari segi optimalisasi penggunaan media maupun peningkatan penjualan. Tolok ukur secara mode transmisi, waktu, konteks, format dan penerimaan.

Meskipun media online ini adalah pilihan pertama dalam berkomunikasi dengan konsumen, bahkan sebelum pandemi Covid-19 terjadi, beberapa pelaku usaha menyampaikan bahwa media online tidak sepenuhnya efektif karena tidak menjamin produk akan laku atau meningkatkan daya beli. Beralihnya ragam produk dalam mengkomunikasikan pesan melalui media ini menjadikan informasi yang beragam sehingga konsumen jenuh dengan banyaknya iklan atau jenis promosi lainnya. Beberapa media online tersebut memang telah digunakan sebelum pandemi terjadi. Hanya saja beberapa pelaku usaha tidak memanfaatkan secara optimal karena sebelumnya beranggapan bahwa usaha jenis UMKM mereka lebih efektif ketika melakukan komunikasi pemasaran secara tatap muka atau penjualan personal.

Hasil wawancara menunjukkan bahwa media online sangat membantu manajemen pemasaran produk UMKM di masa pandemi ini. Meskipun pada akhirnya para pelaku usaha rindu akan padatnya kunjungan konsumen saat komunikasi pemasaran dilakukan secara tatap muka, tetapi optimalisasi media online selama masa pandemi ini adalah keberuntungan dan penyelamat nasib produk UMKM.

\section{KESIMPULAN}

Berdasarkan hasil observasi selama pendampingan UMKM pada mata kuliah Komunikasi Pemasaran dan hasil wawancara dengan para pelaku UMKM tersebut ditemukan bahwa optimalisasi media online pada masa pandemi yang dipergunakan sebagai media promosi pemasaraan adalah tepat. Penggunaan media online yang memberikan dampak transmisi di mana pesan dan interaksi hadir karena media, penyebaran pesan promosi yang tepat dalam hal waktu, konteks pesan yang tepat dengan media yang digunakan dan format yang mudah diterima oleh ragam konsumen serta bentuk penerimaan pesan yang mudah ditangkap oleh dan dari konsumen menjadi sebuah kesimpulan bahwa media online adalah alat bantu yang efektif bagi pemasaran.

Kemerosotan penjualan akibat pandemi Covid-19 yang menuntut setiap orang untuk berperilaku sesuai dengan protokol yaitu pembatasan interaksi langung kepada calon konsumen, menjadikan media online sebagai sebuah solusi yang membantu stabilitas hidup penjualan produk. Meskipun tetap memiliki kekurangan dan hambatan, para pelaku UMKM masih beruntung dapat mempertahankan usaha untuk tetap ada dan hidup karena bantuan dari media online yang selalu hadir baik bagi pelaku usaha maupun bagi para konsumen. 


\section{DAFTAR PUSTAKA}

Chianasta, F. P. dan Wijaya. S. (2014). The impact of marketing promotion through social media on people's buying decision of Lenovo in internet era: A survey of social media users in Indonesia. International Journal of Scientific and Research Publications, 4(1). 1-6.

Dahlan, M. (2017). Peran pengabdian pada masyarakat dalam pemberdayaan usaha mikro, kecil dan menengah (UMKM). Jurnal Pengabdian Kepada Masyarakat, 1(2). 81-86.

Fill, Chris. (2009). Marketing communications: Interactivity, communities, and content (5th ed.). Pearson Education Limited.

Irham, M. (19 Maret 2020). Virus corona: UMKM diterjang pandemi Covid-19 sampai 'kembang kempis'. BBC.com. https://www.bbc.com/indonesia/indonesia-51946817

Kristiyanti, M dan Rahmasari, L. (2015). Website sebagai media pemasaran produk-produk unggulan UMKM di Kota Semarang. Jurnal Aplikasi Manajemen (JAM), 13(2). 186-196.

Moriuchi, E. (2016). Social media marketing: Strategies in utilizing consumer-generated content. Business Expert Press.

Pickton, D. and Broderick, A. (2005). Integrated marketing communication (2ndedition). Pearson Education Limited.

Putri, A. S. (20 Desember 2019). Peran UMKM dalam perekonomian Indonesia. Kompas.com. https://www.kompas.com/skola/read/2019/12/20/120000469/peran-umkm-dalamperekonomian-indonesia?page=al

Simanjorang, S. (6 Juni 2020). Nasib UMKM di tengah pandemi Covid-19. Investor.id. https://investor.id/opinion/nasib-umkm-di-tengah-pandemi-covid19

Wiguna, D. K. S. (19 Juni 2020). Selama pandemi COVID-19, sebanyak 301.115 UMKM beralih ke digital. Antaranews.com. $\quad$ https://www.antaranews.com/berita/1563584/selama-pandemi-covid-19sebanyak-301115-umkm-beralih-ke-digital

Zuraya, N. (4 Februari 2020). Kemenkominfo harapkan UMKM manfaatkan pasar digital. Republika.co.id. https://republika.co.id/berita/q561cd383/kemenkominfo-harapkan-umkm-manfaatkan-pasardigital 